\title{
Otantik Liderliğin Akademik Platformda Lider Boyutu Açısından İncelenmesi
}

\author{
Güzin KIYIK KICIR, Didem PAŞAOĞLU*
}

Otantik Liderliğin Akademik Platformda Lider Boyutu
Açısından İncelenmesi

Özet

Bu çalışmada otantik liderlik yaklaşımı akademik platformda görev alan dekanlar üzerinde sorgulanmıştır. Çalışmanın sorunsallarını otantik liderliğin akademisyenlerde görülme yoğunluğunun ne olduğu, cinsiyetin otantik liderlik davranışlarına nasıl yansıdığı ve farklı disiplinlerden gelmenin tutum ve davranışları ne yönde etkilediği oluşturmaktadır. Araştırmanın amacı görüşülen katılımcılar üzerinde otantik liderlik olgusunu durum saptamasıyla incelemektir. Araştırmada veri toplama aracı olarak derinlemesine görüşme metodu kullanılmaktadır. Toplanan veriler ise geliştirilen veri kodlama cetveli yardımıyla, $\mathrm{N}$-vivo programından destek alınarak içerik analizine tabi tutulmuştur. Sonuç olarak fakülte dekanlarının her birinin otantik liderlikle kesişen ve farklılaşan yanlara sahip ve kadınların otantik liderliğe daha yatkın olduğuna ulaşılırken, sosyal bilimlere oranla, fen ve doğa bilimlerine ait fakültelerde görev alan dekanların cevaplarının kavrama daha yakın özellikler gösterdiği dikkati çekmektedir.

Anahtar Kelimeler: Otantik Liderlik, Akademik Platform, Sinerji, İçerik Analizi
Analysis of Authentic Leadership on Academic Platforms with an eye to Leader Aspect

\section{Abstract}

In this study, authentic leadership approach has been questioned on deans involved in the academic platform. Problematic of the study, what density the authentic leadership is seen in academics, how gender is reflected in behaviors come from different disciplines, and what impact attitudes and behaviors that constitute. The purpose of the study is to examine the phenomenon of authentic leadership. The data collection method is used in-depth interviews. The faculty deans were determined by purposive sampling method. The data collected with data encoding, and Nvivo was used for analysis. As a result, the dean of the faculties are seen in similar and different sides in authentic leadership, and it is found that women have more tendency on authentic leadership and also social sciences deans, and science faculties of the deans answers are indicated close features of concept.

Key Words: Authentic Leadership, Academic Platform, Synergy, Content Analysis

\section{Giriş}

Küreselleşme ile birlikte yaşanan politik, sosyal ve teknolojik gelişmeler, klasik liderlik anlayışlarının yerine yenilerini iş dünyası ve literatüre kazandırmıştır. Lidere ilişkin beklenti ve tanımların değiştiği bu dönemde ortaya çıkan modern liderlik teorilerinden biri otantik liderliktir. Luthans ve Avolio'ya (2003) göre, otantik liderler bireysel farklılıkları anlar ve bunlara değer verir. İnsanların yeteneklerini tanımlama ve onların bu yeteneklerini güce dönüştürmeleri konusunda yardımcı olma motivasyonuna sahiptir. Otantik liderlik, liderin bir unsuru olduğu izleyenle etkileşime dayalı

* Güzin KIYIK KICIR, Uzman Doktor, Anadolu Üniversitesi, Yönetim ve Organizasyon Bölümü, gkiyik@anadolu.edu.tr; Didem PAŞAOĞLU, Yrd. Doç. Dr., Anadolu Üniversitesi, Yönetim ve Organizasyon Bölümü, dpasaoglu@anadolu.edu.tr 


\section{Güzin KIYIK KICIR | Didem PAŞAOĞLU}

bir süreci ifade etmektedir. Otantik liderlik süreci, otantik olan liderin izleyenleriyle açık, şeffaflığı esas alan, başka bir deyişle izleyenlerinin kendisine dair bilgiye olduğu gibi ulaşmasına izin veren bir süreçtir. Otantik liderler, kendisinin olumlu ya da olumsuz tüm yönlerine vakıf olan, var olanla yetinmeyen, değerlerini ilkelerini ve inançlarını esas alan böylece var olanı daha da öteye taşıma çabası içindeki liderlerdir (illies vd., 2005; Wood vd., 2008).

Bu araştırmada otantik liderlik ve alt boyutlarının cinsiyet ayrımına göre farklılaşıp farklılaşmadığı da irdelenmektedir. Kadın sayısının üst liderlik rollerindeki azlığı yeni değildir ve uluslararası göstergelerle açılanabilir. Kadınların yönetsel rollerdeki yüzdesi \%25'ten (Almanya) \%43'e (Avustralya) değişkenlik gösterirken kadınların kıdemli pozisyonlardaki oranları \%0,3 ve \% 5 (Japonya ve Almanya) arasındadır, Avustralya'da \%15, ABD'de \%10'dur (Özdil Aydın, 2009). Bu farklılıkların sosyal ve örgütsel ortamdaki potansiyel etkilerini açıklamaya yönelik araştırmalar ve bulgular da vardır. Boatwright ve Forest (2000) liderlik pozisyonlarındaki sayısal farklılıklar için bir neden olan cam tavan (glass ceiling) kavramını vurgulamaktadır. Ayrımcılık ve kalıp yargı örnekleri de kadın liderlerin sayılarının düşüklüğüne yol açabilir. Örgütsel liderlik rollerindeki cinsiyet eşitsizliğinin iş ahlakının bir sorunu olduğu ileri sürülmüştür (Stelter, 2002). Kadının Statüsü Genel Müdürlüğü’nün 2012 verilerine göre Türkiye'de kamu kurumlarında kadın sayısı; müsteşar, başkan, genel müdür, daire başkanı, bölge müdürü, il müdürü ve bu kadroların yardımcıları pozisyonlarında \% 0-20 arasındadır.

\section{Otantik Liderlik}

Harter (2002), otantiklik kavramını; kişinin kendi deneyimlerine bağlı olarak duygu, düşünce, intiyaç, istek, öncelik ya da inançlarını kabullenmesine yani "kendini bilmesine" dayalı bir süreç olarak açıklar ve kendi içyapısıyla uyumlu bir şekilde gerçek duygularını yadsımadan düşünmeyi ve davranmayı gerektirdiğini ifade eder (Avolio ve Gardner, 2005, 320). Harter"ın (2002) bu tanımına göre otantiklik, insanın düşünce ve duyguları ile davranışlarının paralel olması anlamını taşımaktadır. Avolia ve meslektaşları (2004), otantik liderliği dönüşümcü liderlik ile etik liderliğin harmanlandığı bir temel yapı olarak ele almıştır. Dönüşümcü liderlikte belirtildiği gibi (Avolio, 1999), otantik liderler yol gösterici ya da katılımcı ve hatta otoriter olabilmektedir. Otantik liderler itibar oluşturmak ve onları takip edenlerin saygısını ve güvenini kazanmak için derin kişisel değer ve inançları doğrultusunda hareket eden kişilerdir. İzlediği bu idarecilik yolu sayesinde takipçileri tarafından otantik lider olarak tanınmaktadırlar.

George’a (2003) göre, otantik liderler diğer insanlara gerçekten liderlikle hizmet etme arzusundadır. Onlar, fark yaratmak için yönettikleri insanlara yetki vermeye heveslidir. Ayrıca, yönettikleri insanları mantığın yanında vicdan, tutku ve merhamet gibi özelliklerle de donanmış olmak üzere yönlendirir. Otantiklik, çalışanların gelişimi, iyiliği ve kendilerini tanımaları için şarttır (llies vd., 2005 , s. 374). Nitekim otantik kurumlarda liderler ve çalışanlar birbirlerindeki gelişme potansiyelini açığa çıkarmak için çalışmaktadır (Dorn vd., 2005). 


\section{Otantik Liderliğin Unsurları}

Örgütlerde olumlu bir iklim yaratabilen otantik liderliğin geliştirilmesi sürecinde bazı unsurlara intiyaç duyulur. Kendi kendine yetebilme/kendine güven, umut, iyimserlik ve sorunların çabuk üstesinden gelebilme niteliklerini içeren psikolojik sermaye otantik liderliğin temel elemanlarındandır (Luthans ve Youssef, 2004: 152). Ayrıca otantik karar verme süreci, öz bilinç ve kendini ayarlama yetileri geliştirme ve örgütsel bağlam da sözü edilen unsurlardan oluşmaktadır (Kesken, Ayyıldız, 2008). Otantik liderlik kapsamında bilinen ve bu araştırma da değerlendirme kriteri olarak kabul edilen dört unsur ise şunlardır: Öz farkındalık, dengeli yönlendirme, içselleştirilen ahlaki bakış açısı ve ilişkisel şeffaflık (Walumbwa vd., 2010).

\section{1. Öz Farkındalık}

Öz farkındalık; bir bireyin kendi güdüleri, duyguları, istekleri ve kendisiyle ilgili bilginin farkında olması ve bunlara güvenmesini esas almaktadır. İçeriğinde kişinin kendi yeteneklerini, zayıflıklarını, karakter özeliklerini ve duygularını bilmesi yer almaktadır ve bu bileşen sadece bununla da sınırlı değildir. Kişinin ihtiyaçları, değer yargıları, hisleri, kişilik özellikleri ve bunların davranışlarındaki yerini de içermektedir. Ayrıca bu kavram, psikolojik sağlığın önemli bir belirleyicisidir (Kernis,2003).

Öz farkındalık kişinin kendinin farkında olması ve buna güvenmesini ifade eder. Bireyin kişisel özelliklerini, değerlerini, duygularını, güdülerini bilmesidir (llies, Morgeson, Nahrgang, 2005). Öz farkındalık, liderlerin kendilerine özgü yeteneklerini, bilgi ve deneyimlerini anlayarak bunları geliştirme süreci olarak nitelenmiştir (Avolio ve Gardner, 2005). Özellikle liderlerin temel değerleri ve zihinsel modelleri ile ilgili netlik sağlamak için önemli bir mekanizma olan kendini yansıtma (self reflection) ile bağlantılı bir kavramdır (Gardner, Avolio, Luthans, May, Walumbwa, 2005).

\section{2. Bilgiyi Dengeli ve Tarafsız Değerlendirme}

Otantik liderliğin bir diğer unsuru bilgiyi dengeli ve tarafsız değerlendirebilmedir. Avolio ve arkadaşları (2009), dengeli yönlendirmeyi, bir karar vermeden önce ilgili verileri tarafsı olarak değerlendirmek alarak tanımlamışlardır. Adından da anlaşılabileceği gibi, bu terim, katkı peşinde koşulan ve savunmacı olunmayan bir tutumla başkalarının fikirlerinin değerlendirmeye alındığı faal bir durumu ifade eder. Öncesinde, Kernis (2003), tarafsızlığı, kabul etmeyi ve kendi kendini değerlendirmeyi gerektiren "önyargısız yönlendirme"nin, otantik liderliğin temel ögelerinden bir tanesi olduğunu savunmuştu. Kişinin kendi kendisine dair "tarafsız" bir bakış açısı edinmesinin pek mümkün olmadığı görüşüne cevaben, Avolio ve Gardner (2005), "dengeli değerlendirmeyi” ortaya çıkarmışlardır. Dengeli değerlendirme, karar vermeden önce tarafsız bir şekilde bütün ilişkili verileri analiz etmek demektir (Walumbwa, Avolio, Gardner, Wernsing, 2008). Bu kavram, kusursuz bir tarafsızlık öngörmüyor, fakat, yine de liderlerin kendi egolarını tehdit etmeksizin kendileri ile ilgili olumlu ya da olumsuz bilgi toplayabileceklerini ve bu bilgileri değerlendirebileceklerini savunuyordu (Gardner vd., 2005).

Gerek iç gözlemlerle, gerekse dış değerlendirmelerle öz farkındalıklarını artıran otantik liderler, edinilen bilgileri abartmadan, bozmadan, göz ardı etmeden, tarafsı olarak kullanırlar (Kernis, 


\section{Güzin KIYIK KICIR | Didem PAŞAOĞLU}

2003). Tarafsız karar verme, kişisel dürüstlüğün ve karakterin kalbidir. Karakter ve dürüstlük sadece liderin kararlarını ve eylemlerini değil, aynı zamanda kendi iyiliği hakkındaki sezgilerini de etkilemektedir (llies, Morgeson, Nahrgang, 2005). Kendisi hakkındaki bilgisini tarafsı değerlendiren liderler, elde edilen verileri daha hatasız olarak yorumlayıp, beceri düzeyini daha iyi değerlendirebilir (Csikszentmihalyi, 2003). Daha tarafsız değerlendirme yapabilen liderler elde edilen verileri daha hatasız olarak yorumlamakta, becerilerini daha iyi değerlendirmekte ve öğrenme potansiyellerindeki zorlayıcı şartları aramaktadır (Ilies, Morgeson, Nahrgang, 2005).

\section{3. İçselleştirilmiş Ahlak Anlayışı}

Bu özellik, kişinin davranışlarını yöneten içsel ahlaki standartları ifade eden bir bakış açısı ya da ahlaki öz-kimliktir (Avolio vd., 2009). Otantik liderliğin çekici özelliklerinden bir tanesi, otantik liderlerin, kendi ahlaki "iç pusulalarını", özellikle de belirsiz ahlaki durumlarda ya da kişinin gayri-ahlaki bir davranışa zorlandığı durumlarda uygun davranışlarda bulunmaya odaklı olarak kullanabilmeleridir (George ve Sims, 2007; May vd., 2003). Güçlü ahlaki kimlikleri olan kişiler yalnızca gayri-ahlaki davranışlarda bulunmaya zorlanmazlar (Colby ve Damon, 1992; Galperin vd., 2011; Shao vd., 2008; Treviño vd., 2006), aynı zamanda gönüllülük gerektiren faaliyetlerde bulunma ya da çeşitli fonlara bağışta bulunma gibi toplum yanlısı davranışlara da daha eğilimlidirler (Aquino ve Reed, 2002). Luthans, Avolio (2003), May ve arkadaşları (2003) ayrıca Avolio ile Gardner (2005) otantik liderlik yapısının olumlu bir ahlaki/etik bileşene ihtiyacı olduğunu ileri sürmektedir. Özellikle ahlaki ikilemleri çözebilmek için liderin doğasında; üst düzey ahlaki standartlar ve yetenekler olduğunu ifade etmektedir. İçselleştirilmiş ahlak anlayışı, kişinin değer kalıpları, seçimleri ve gereksinimleri ile uyum içinde davranışlar sergilemesi anlamına gelmektedir (Kernis, 2003).

\section{4. Iliş̧ilerde Şeffaflık}

Otantik liderliğin son özelliği ilişkilerde kullanmayı tercih ettiği şeffaflıktır. Şeffaflık kendini açık ve doğru biçimde ifade etme yeteneklerinin tümünü kapsar (llies, Morgeson, Nahrgang, 2005). Bu özellik insanların, liderlerinin otantik lider özellikleri olduğunu düşünmelerini sağlayan, çeşitli durumlara uygun olan bilgi ve hislerin paylaşılmasıdır (Avolio vd., 2009). Nitekim, otantik liderliğin önemli hedeflerinden biri, otantik modelleme ile takipçilerde bir açıklık hissi yaratmak ve böylece takipçilerin, kendilerini liderler ile özdeşleştirmeleri ve liderlerin olumlu özelliklerini kendilerine örnek almalarını sağlamaktır (Luthans ve Avolio, 2003; Luthans vd., 2006). Ortak bir grup kimliğini teşvik etmek için şeffaflık önemlidir. Otantik liderler hislerini uygun bir biçimde dışa vururken (Avolio vd., 2004; Gardner vd., 2005) olumsuz dışa vurum daha az gelişir.

Otantik liderler hedefleri, güdüleri, değerleri, kimlikleri ve duyguları ile kendilerinin farkındadır. Ayrıca dengeli ve uyumlu olmalarının yanı sıra takipçilerine karşı ilişkilerinde de şeffaftırlar (Mazutis \& Slawinski, 2008). Gardner ve arkadaşları (2005) otantik liderlerin kendi gerçek duygularını ve hislerini takipçilerine yansıtırken şeffaf olmalarının yanı sıra aynı zamanda bu duyguları uygun olmayan ve zarar verebilecek bir tutumdan arındıracak şekilde disipline ettiklerini ifade etmektedir. Kişinin takipçilerine karşı kendini gerçekçi şekilde ifade etmesi, güveni ve samimiyeti oluşturur. Bu 
da takipçileri takım çalışmasına ve işbirliğine teşvik eder (Gardner, Avolio, Luthans, May, Walumbwa, 2005). Gardner ve arkadaşlarının (2005) çalışmalarını temel alan Hughes (2005), ilişkilerde şeffaflı̆ı̆n dört unsurunun altını çizmiştir. Bu unsurlar; hedefler, kimlik, değerler ve duygular$\operatorname{dir}($ HKDD).

\section{Otantik Liderlik ve Sinerji}

Otantik Liderlik, kişilerin pozitif yönlü olmalarını ve bu anlamda kendilerini daha güçlü hissetmelerini sağlayan, vizyonlarını geliştiren, kararlarında neyin doğru olacağını düşünmelerine dayalı bir duyarlılık oluşturan, örgütsel bağlamda performanslarını arttırma yönünde çaba sarf etmelerine etkide bulunan, yüksek güvene dayalı bir liderlik yaklaşımıdır (Avolio vd, 2004). Otantik liderler, grup içinde ya da grup dışında edindikleri tüm bilgileri hem analiz etmede, hem de değerlendirme sürecinde grup üyeleriyle şeffaflığı temel alan bir anlayışla paylaşmaktan çekinmez. Bu anlamda fikir alış verişinin yarattığı sinerjiyi tüm grubu güçlendirmeye ve geliştirmeye kanalize ederler (Walumbwa vd. 2011; 7-8).

İnsanlar ilişki kurarlarken güven duyabilecekleri kişilerle ilişki kurmaya özen gösterir. Liderinde sinerji oluşturacak bir yönetim anlayışına gidebilmesi ve ilişkileri yönetebilmesinde güven son derece önemlidir. Güven iyi niyetle ortaya koyulan jestlerin, gelecekteki herhangi bir zamanda herhangi bir beklentiye dönük olmadan yapılmasını belirtir (Gardner vd, 2005, 364). Otantik liderler, izleyenleriyle ilişkilerini, sağlam ve güçlü temellere kurarlar. Böylece her iki taraf da ortaya koydukları eylemlerinin inançlarıyla uyumlu olduğunu bilir ve neyi başarmaları gerektiğinin farkında olur. Şekil 1'de Ward'a (2006) göre otantiklik ve güven arasındaki birbirini pekiştiren ilişkiyi görmek mümkündür. 


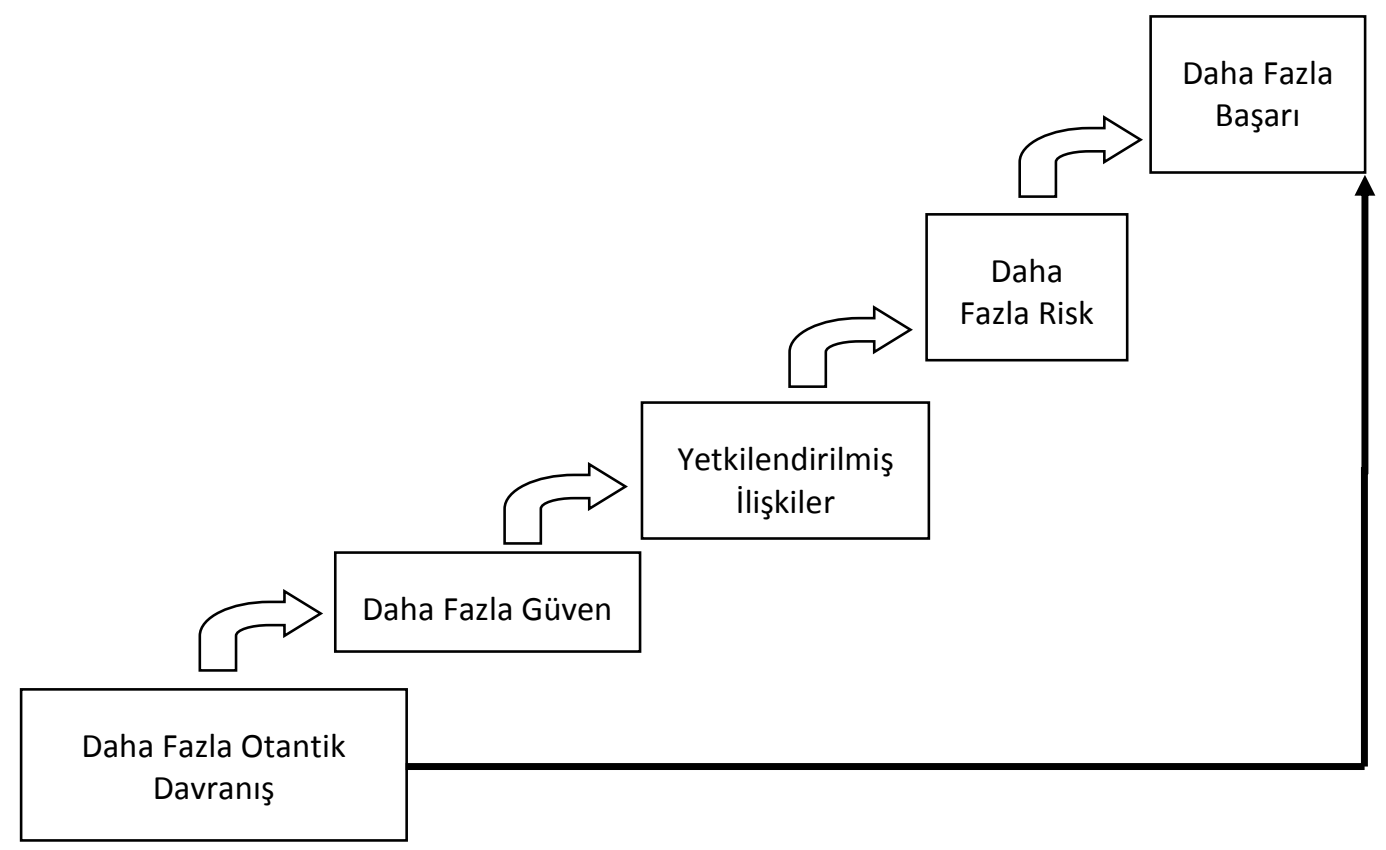

Şekil 1. Otantiklik Sinerjiyi Tetikler (Ward, 2006)

\section{Otantik Liderlerin Özellikleri}

Yazında otantik liderin örgütsel sonuçları olumlu etkileyebilecek birçok niteliğe sahip olduğu görülmektedir. Shamir ve Eilam (2005, 396-399), karakteristik bu özellikleri şöyle sıralamaktadır.

- Otantik liderler, "lider taklidi" yapmazlar. Diğer bir deyişle lider olmanın sorumluluklarını yerine getirirken sadece kendileri olur, başkaları liderliğiyle ilgili ne düşünür kaygısına kapilmazlar.

- $\quad$ Otantik liderler, statü, şeref ya da kişisel mükâfatlar için liderlik rolüne bürünmezler. Liderliği inançla yürütür. Liderliğin gerektirdiği misyonları değerlere dayalı sürdürürler.

- Otantik liderler "kopya" değildir. Değer ve inançlarını deneyimleriyle harmanlayıp içselleştirir.

- Otantik liderler, eylemlerini sahip oldukları değerlere ve inanca dayandırır. Konuşmaları ve davranışları inandıklarıyla tutarlıdır. Bu liderler, sosyal, politik bir çıkar uğruna ya da popülaritesini arttırmak adına değil, değerleri ve inançları ne gerektiriyorsa öyle hareket eder. 
Otantik liderlik başlığı altında Kesken ve Ayyıldız'ın (2008) çalışmalarında daha kapsamlı olarak derleyip belirttiği özelikler ise şunlardır:

- Bireysel değerleri faaliyetlerle, faaliyetleri de örgütsel değerler ile bağdaştırmaya çalışır (Luthans ve Avolio, 2003, s. 243; Dorn vd., 2005).

- Insanlara hizmet etmek isterler ve çalışanlarını güçlendirir.

- Aklın yanı sıra merhamet, tutku gibi duygular ile hareket eder.

- Otantik liderler doğuştan bu özelliklere sahip değildirler ama bu özelliklerini geliştirmeye çalışır, eksikliklerini giderir (George, 2003, s. 12).

- Güçlü-yerleşik kurum kültürü ve sosyal kültürlerde nasıl kabul göreceğini ve radikal bir değişim gerçekleştirmek için hangi kültürel değerlerden yararlanması gerektiğini bilir (Goffee ve Jones, 2005).

- Kendilerine karşı dürüsttür. Başkalarının beklentilerine uymak adına kişiliklerinden ödün vermezler.

- Statü, kişisel çıkarlar yerine sosyal çıkarlarla güdülenir.

- Taklit değil, orijinaldir.

- Davranışlarının temelini değer ve kanaatleri oluşturur (Avolio ve Gardner; 2005 s. 321).

\section{Yöntem}

$\mathrm{Bu}$ araştırmada veriler yarı yapılandırıımış derinlemesine görüşme metoduyla toplanmıştır. Görüşme soruları Walumbwa ve arkadaşlarından (2008) uyarlanan, güvenilirlik geçerliliği kabul görmüş “Otantik Liderlik Ölçeğinden” destek alınarak hazırlanmıştır. Örneklem belirlenirken amaçlı örnekleme yöntemleri arasındaki maksimum çeşitlilik örneklemesi kullanılmaktadır. Bu yöntemde göreli olarak oluşturulan küçük bir örneklemde, çalışılan probleme taraf olabilecek bireylerin çeşitliliğinin maksimum derecede yansıtılması amaçlanır. Uygulama için seçilen üniversitede dekanların cinsiyetleri ve fakültelerinin bilimsel alanlarına ilişkin dengeli dağılımı sağlamak amacıyla maksimum çeşitlilik örneklemesine başvurulmuştur. Görüşme deşifreleri, N-vivo 8 programı aracilığıyla, içerik analizine tabi tutulmuştur. İçerik analizi, nitel veri analiz türleri arasında en sık kullanılan yöntemlerden biridir (Özdemir, 2011). İçerik analizinde temelde yapılan işlem, birbirine benzeyen verileri belirli kavramlar ve temalar çerçevesinde bir araya getirip, bunları okuyucunun anlayabileceği biçimde düzenleyerek yorumlamaktır (Yıldırım ve Şimşek, 2006). Araştırmacı daha sonra, incelenen veri setinde, bu kategoriler içerisine giren kelime, cümle ya da resim gibi referansları saymaktadır (Özdemir, 2011). İçerik analizi referanslara ilişkin sayı ve yüzdeleri barındırsa da nitel eğilimli bir yöntemdir. Bu nedenle çalışmada elde edilen sonuçlar örneklem için anlamlıdır ancak genellenirlik konusunda sınırlılı̆a sahiptir. Çalışmadaki değerlendirme kriterleri literatürden destek alınarak oluşturulmuş ve iki farkı ılan uzmanı tarafından kodlanmıştı. Araştırmada 3 ana veri kodu ve 14 alt tema bulunmaktadır. Okuyucunun zihninde kavramsal bir akış oluşturulması, analiz bo- 


\section{Güzin KIYIK KICIR | Didem PAŞAOĞLU}

yutlarının bütüncül olarak algılanabilmesi, araştırma odağının kaybedilmemesi ve çalışmada örtük bir yan kalmaması için veri setine ilişkin tüm temalar Tablo 1'de verilmiştir.

Tablo 1. Araştırmanın Veri Kodlama Cetveli

Veri Kodlama Cetveli

1. Otantik Liderliğin Unsurları

1.a Öz Farkındalık

1.b Bilgiyi Dengeli ve Tarafsız Değerlendirme

1.c İçselleştirilmiş Ahlak Anlayışı

1.d ilişkilerde Şeffaflık

2. Otantik Liderlik ve Sinerji

2.a Çalışanlarla Daha Fazla Karşılıklı Güven Oluşturma

2.b Yetki Verip Çalışanlarla İlişkileri Güçlendirme

2.c Daha Fazla Risk Alma Davranışının Görülmesi

2.d Bireysel ve Örgütsel Başarıda Artış

3. Otantik Lider Özellikleri

3.a Otantik Lider Aklın Yanı sıra Merhamet, Tutku Gibi Duygularla Hareket Eder.

3.b Kendilerine Karşı Dürüsttür, Başkalarına Uymak Amaçı Ödün Vermez.

3.c Davranışlarının Temelini Değer Yargıları ve Kanaatleri Oluşturur.

3.d Statü, Kişisel Çıkarlar Yerine, Sosyal Çıkarlarla Güdülenir.

3.e İnsanlara Hizmet Etmek İster ve Çalışanlarını Güçlendirir.

3.f Doğuştan Bu Özelliklere Sahip Değildir. Özelliklerini Sonradan Geliştirmeye Çalışır.

Görüşme metinleri, ses kayıtları, fotoğraf ve video gibi belgeler üzerinde analiz yapmaya olanak tanıyan "N-vivo" da gösterilen bilgileri içeren programa ait örnek görsel Tablo 2'de yer almaktadır. 
Eskişehir Osmangazi Üniversitesi Sosyal Bilimler Dergisi

Tablo 2. Örnek N-vivo Görseli

Örnek N-vivo Görseli

<Internals \1. Fakülte Dekanı - § 1 reference coded [1,97\% Coverage]

Reference 1 - 1,97\% Coverage

"Ben, her şeyi ben yaparım tarzında bir adam değilimdir. Herkese sorarım öğrenirim ve o işin, o arkadaş tarafından yapılmasını isterim."

Referans bilgileri yukarıdaki gösterim şekliyle verilmiştir. "1. Fakülte Dekanı" referansın 1. Fakülte dekanıyla yapılan görüşmelerin deşifresiyle elde edilen dökümlerden çıkartıldığını göstermektedir. "§ 1 reference coded" ilgili kod altında, dokümandan kaç tane referans alındığını ifade etmektedir. Yukarıdaki örnek için referans sayısı birdir. "[1,97\% Coverage]" dokümandan ilgili kodlamaya yapılan tüm referansların dokümanın yüzde kaçı olduğunu gösterir. Yukarıdaki örnek için 1,97'dir. "Reference 1- 1,97\% Coverage" dokümandan ilgili koda yapılan birinci referansı ve bu referansın dokümanın ne kadarlık bir kısmını kapsadığını göstermektedir. Referans bilgilerinin altındaki ifade ise örnek bir alıntı metnidir. Raporlama kısmında ilgili referanslar parantez içerisinde ilgili dokümanın ismi ve referanslara ait satır numaraları verilerek gösterilmiştir Örnek: (“1. Fakülte Dekanı" str 23-25).

\section{Bulgular}

Araştırmadaki ilk kod otantik liderliğin bileşenleri içerisinde yer alan öz farkındalıktır. Bireyin kendi güdüleri, duyguları, istekleri ve kendiyle ilgili bilgilerin farkında olması anlamına gelen bu temada 19 referans tespit edilmiştir. 1. fakültede konuyla ilgili 1, 2. fakültede 11,3 . fakültede 3 ve son olarak 4. fakültede 4 tane referans, öz farkındalık temasıyla ilişkilendirilmiştir. Araştırma kapsamında görüşülen ilk dekan öz farkındalık noktasında her şeyi bilen bir insan havasında davranmadığını dile getirmiş, bir iş yaparken çalışma arkadaşlarına soran danışan bir tarzı olduğunu ifade etmiştir (“1. Fakülte Dekanı” str 81-82). Görüşme yapılan 2. dekan imalı konuşmayan, hata yaptığında sorumluluk alıp üzülen, akademisyenliğe ilişkin değer yargıları olan, içi başka dışı başka insanları sevmediğini dile getiren, zoru seven, yeri geldiğinde kendisiyle ilgili olumsuz düşünceleri duymayı isteyen ve bir karar vereceği zaman, ayrıntılı düşünüp sonra tekrar o karara kesinlikle dönmeyen bir yönetici profili oluşturmuştur ("2. Fakülte Dekanı" str 4-5, 9, 110-111, 117-119, 132-133, 160-161, 243-244). Görüşmelerde 3. dekan hem kendi egolarıyla, hem de başkalarının egolarıyla uğraşmanın zorluklarını bilen, kolay kolay sinirlenmeyen, rahatsız da olsa kendisini kontrol etmeye çalışan ve en çok haksızlığa uğradığında demoralize olduğunu kabul ederek kendi öz farkındalığına ilişkin cümleler kullanmıştır (“3. Fakülte Dekanı” str 102-106, 147-150, 154-156). Bu kod başlı̆̆ altında görüşülen son, yani 4. dekan ise; yeni bir atılım yaparken, sürecin takibini uzaktan yapmak yerine, inandırıcı olması adına en başta kendisi örnek olmayı tercih eden, empati yeteneği yüksek, herkesi dinleyen ancak kendi kurallarını da yeri geldiğinde koruyan bir yapı çizmiştir ("4. Fakülte Dekanı" str 76-79, 87, 315-316, 325-328). 


\section{Güzin KIYIK KICIR | Didem PAŞAOĞLU}

Çalışma kapsamında otantik liderlik öz bileşenleri içerisinde ikinci kod başlığı, bilgiyi dengeli ve tarafsız değerlendirmedir. Burada liderin bilgiyi tarafsız değerlendirip, hatasız yorumlayabilme becerisi ve bir karar vermeden önce konuyla ilişkili bütün verileri analiz edebilen bir yana sahip olup olmadığı sorgulanmaktadır. Bu kapsamda tespit edilen 19 referansın, 2 tanesi 1 . fakülteye, 10 tanesi 2. fakülteye, 4 tanesi 3. fakülteye ve 3 tanesi de 4 . fakülteye aittir. Illk dekanın söyleminde; bir konuyla ilgili karar verme aşamasına gelindiğinde başkalarının fikirlerini aldığı, tek bir kişiyi değil çoğunluğun dediklerini önemsediği ve zaman zaman tek taraflı aldığı kararlarda dahi mutlaka karşı tarafı dinlemeye çalıştığı anlaşılmaktadır ("1. Fakülte Dekanı" str 47-49, 56-58). Araştırmada bilginin tarafsız değerlendirilmesi başlığı altında gelen yanıtlardan, 2. dekanın, işyerindeki görev tanımlarını çıkarıp, standartlar belirleyerek tüm çalışanlarını objektif değerlendirmeye çalıştığı görülmüştür. Ayrıca dekanın gençlerin fikirlerini alan, inandığı değerlere ters olsa da farklı görüşlerin belirtilmesini ısrarla isteyen, karar almadan önce araştıran, ayrıntılı bir şekilde çalışan ve son olarak ilgili yönetmelik ve yasaları okuyup karar veren bir profil çizdiği dikkati çekmektedir ("2 Fakülte Dekanı" str 42-43, 85-88, 141, 151-154, 166-169). Kişiler hakkında karar verirken o kişiyi her yönüyle değerlendirmeye çalışan 3. dekan ise, fakültesi adına bir rapor sunmadan önce, zorunluluğu olmamasına rağmen tüm akademik personelin görüş ve fikirlerini almak için çabaladığını, bu anlamda karşıt görüşlerin alınan kararları beslediğini ifade etmiştir. Yoğunluğu nedeniyle bazen istediği kadar konuları inceleyemese de, 3 dekan önemli kararlar almadan önce mutlaka araştırma yaptığını da belirtmiştir. Ayrıca yeri geldiğinde karşıt görüşlerin doğru olduğunu kabul eden bir yönetici olduğunu ifade etmiştir (“3. Fakülte Dekanı” str 80-81, 96-102, 113-117, 141-144). Bu temada son olarak 4. fakülte dekanı ise zaman zaman hızlı karar almak gerektiğini dile getirmiş ancak hızlı alınan kararlarda hata yapma riskinin arttığını vurgulamıştır. Bununla beraber şimdiye kadar öğrendiği en önemli şeyin, gerçekleri her iki taraftan dinlemeden karar alınmaması gerektiği ifadesi olmuştur (“4. Fakülte Dekanı” str 67-70, 138-143).

Araştırmadaki diğer bir kod olan içselleştirilmiş ahlak, otantik liderin sahip olduğu değer kalıpları ve üst düzey etik anlayışı ile ilgili düşüncelerini temsil etmektedir. Bu tema altında toplamda 17 referans ile karşılaşıımış, bunların $5^{\prime} \mathrm{i}, 1$. fakülte, 4'ü, 2. fakülte, 5'i, 3. fakülte ve son olarak 3'ü, 4 . fakülteye aittir. Araştırmada görüşme yapılan ilk dekan içselleştirilmiş ahlak konusunda hatalarını kabul edebildiğini, hatta kendisine ait olmasa da sonuçları kurumu etkilediği için başkalarının hatalarını bile üstlenebilen bir sorumluluk anlayışına sahip olduğunu ifade etmiştir. Kurumun çıkarları için zaman zaman yapmam dediği şeyleri yaparak ödün verebildiğini dile getiren 1 . dekan, bununla beraber etik açıdan sıkıntılı bir durum olduğunda veya birden çok kişiden olumsuz dönütler geldiğinde kişilerle ilgili sert kararları kolaylıkla alabildiğini de sözlerine eklemiştir ("1. Fakülte Dekanı" str 8-9, 22-25, 37-38, 52-53). Görüşme yapılan 2. dekan, içi başka, dışı başka söylemlerden hoşlanmadığını, ancak bunu kişiselleştirmediğini ifade etmiş, çalışma arkadaşları ile profesyonellik çerçevesinde ilişkiler kurduğunu, kendisi için önemli olanın yapılan iş olduğunu dile getirmiştir ("2. Fakülte Dekanı" str 100-105, 117-120). Otantik liderin ahlak anlayışı konusunda 3. dekandan gelen yanıtlardan, dekanın kendisinde yakaladığı hataları kabul eden bir anlayışa sahip olduğu ve en çekindiği konunun insanlar arasında kayırmacılık yaptığının düşünülmesi olduğu ortaya çıkmıştır. Hatta bu 
nedenle dekan, insanlara genelde iş odaklı yaklaşmaya çalıştı̆ının da altını çizmiştir ("3. Fakülte Dekanı" str 5-8, 159-167). Bu temada görüş belirten 4. dekan, etik ve ahlaki kurallara aldığı kararlarda öncelikle dikkat ettiğini ifade ederken, herkesin bakış açısına saygı duyduğunu ve ayrıca hatalardan ders çıkarabilmeyi önemsediğini içselleştirilmiş ahlak konusu altında dile getirmiştir ("4. Fakülte Dekanı" str 17-22, 93-94, 101-103).

İlk kod grubundaki son başlık olan ilişkilerde şeffaflık, liderin yüksek düzeyde açık iletişim kurması ve kendi gerçek benliğini takipçisinin görmesine yardımcı olma çabasını ifade etmektedir. Araştırmada en çok referansı alan bu temada görüşme kayıtlarından toplam 35 alıntı yapılmıştır. Bunların 3'ü, ilk fakülteye, $11^{\prime} i$, 2 . fakülteye, 10 tanesi, 3. fakülteye ve $11^{\prime} i$ ise 4 . fakülteye aittir. Görüşme yapılan dekanlardan ilki iletişimde acı gerçekleri ifade etme noktasında endirekt olmayı tercih ettiğini belirtmiş, kızgınlıklarını içinde biriktirip en son noktaya geldiğinde patlama yaşadığını sözlerine eklemiştir. Ayrıca hayatındaki kişisel durumları çalışanlarına yansıtmadığının da altını çizerek iletişim biçimini açıklamıştır (“1. Fakülte Dekanı” str 3-4, 18-20, 78). Görüşme yapılan 2. dekan asla dolambaçıı imaları sevmediğini ve yönetimlerin açık olmasından yana olduğunu söylemiş, ancak olumsuzu söylemenin, olumluyu söylemekten daha zor olduğunun da altını çizmiştir. Üst düzey toplantılarda alınan kararları hemen sonrasında, çalışanlarıyla paylaştığı için pek çok genç meslektaşı tarafından açık bir yönetici olarak tanımlandığını ifade etmektedir. Ayrıca zorunlu olmadığı halde periyoduk dönemlerde hazırladığı bilgilendirme raporlarını çalışma arkadaşlarıyla paylaştığında duyduğu rahatlamayı dile getirmiştir. İşle ilgili süreçlerde bilgi paylaşımına açıkken özel hayatını bu sürecin dışında ve kapalı tutmayı tercih eden 2 . dekan, sadece işe yansıyacak sağlık sorunları hakkında bilgilendirme gereği duymaktadır. ilişkilerde şeffaflık noktasında 2. dekanın kendisini kapattığı nokta ise profesyonellik gereği sevmediği insanlarla dahi hislerini dışa vurmadan iletişim kurabildiğini belirttiği ifadelerde dikkati çekmiştir ("2. Fakülte Dekanı” str 3-4, 5, 52-53, 5456, 71-75, 185-191, 234-239, 247-249). Görüşme yapılan 3. fakülte dekanı, iletişim kurma noktasında karşısındakinin anlayabileceği açıklıkta düşüncelerini söylemeyi tercih ettiğini ve acı gerçekleri acıtmadan söyleme çabası içerisinde olduğunu belirtmiştir. Profesyonellik çerçevesi gereği tarzını beğenmediği insanlarla bile konuşabildiğini ifade eden 3. dekan, yönetici olarak bu noktada duyguları gizlemek gerektiğini sözlerine eklemiş, hatta zaman zaman sinirli olduğu anlarda kimseyle görüşmeyip, kızgınlığı geçene kadar kendisini iletişime kapattığını da ifade etmiştir. İletişimde şeffaflık için özellikle alınan kararlarda herkesin düşüncesini almaya, insanlarla empati kurmaya ve gerektiğinde insanları yanına çağırarak değil, onların kapılarını çalarak kişilerden geri dönütler almaya çalıştığını dile getirmiştir (“Fakülte 3 Dekanı” str 2-3, 21-23, 27-30, 119-121, 125-127, 149-150, 163). Görüşmede 4. dekan, kapısının her zaman açık olduğunu belirterek sürekli iletişimi önemsediğini vurgulamıştır. Ayrıca iletişim kurarken lafı dolandırmadan net olarak ifade etmekte yarar olduğunu, çünkü gerektiğinde ikna sürecine ancak bu şekilde geçilebileceğini söylemiştir. Zorunluluk olmamasına rağmen akademik personel ve öğrencilerle ayda bir toplantılar yapan dekan, içinde bulunduğu sürekli iletişim sürecinin altını bir kez daha çizmiştir. Görüşmeden çıkan bulgulardan bir diğeri de dekanın incitici konularda hassas bir üslupla iletişim kurmayı tercih ettiği ve duygularını bastırdığı için kendi özelini paylaşmayı sevmediği olmuştur. Fakültesinde iletişim konusunda eksiklik hissettiği için uzmanlardan destek alarak, kurum içi iletişimi geliştirmeye çalışan 4. dekan, son 


\section{Güzin KIYIK KICIR | Didem PAŞAOĞLU}

olarak geri dönüt noktasında memnuniyet anketleriyle hem öğrencilerden, hem de çalışanlardan bilgi almaya çalışıklarını sözlerine eklemiştir (“4. Fakülte Dekanı” str 3-5, 9-13, 34-37, 55-57, 158165).

Veri kodlamalarındaki ikinci ana başlık otantik liderliğin sinerjiye etkisidir. Bu başlık altındaki ilk tema çalışanlarla daha fazla karşılıklı güven oluşturma adımıdır. Bu kategoride toplam 17 referans tespit edilmiştir. Bu referansların 3'ü, 1. fakülte, 4'ü, 2. fakülte, 2'si, 3. fakülte ve 8'i, 4. fakülteden gelmiştir. Görüşme yapılan 1 . dekan bu konuda verdiği yanıtlarda akademik personelin düşüncelerini söylemesini teşvik ettiğini, genel geçer şeylere uygun davranma zorunluluğu getirmeden kişilerinde değer yargıları olduğunu önemseyerek ve onlara gerçek anlamda sorumluluğu bırakarak güvene dayalı bir ilişki kurmaya çalıştığını ifade etmiştir. Hatta gerçek anlamda sorumluluk verildiğinde kurum yöneticisi olarak kendisinin zarar görmemesi adına personelinin daha iyi çalıştığını da dile getirmiştir (“1. Fakülte Dekanı” str 11, 29-31, 82-87). Görüşme yapılan 2. dekan ise öğretim elemanlarına hesap vermek durumunda olmamasına rağmen çalışma arkadaşlarına yaptığı icraatlar konusunda sıklıkla rapor verdiğini ve bunu yapınca kendisini rahat hissettiğini belirterek arada güvene dayalı bir ilişki kurmak adına adımlar attığını söylemiştir. Ayrıca gençlerin sessiz kalmaması adına onlara sıkıkla söz vermeye çalıştığının altını çizmiştir (“2. Fakülte Dekanı” str 42-44, 187-189, 210-211). Yapılan görüşmelerde 3. dekan, güven oluşturmak adına katılımcı bir yönetim anlayışı benimsediğini ve sıklıkla yaptığı toplantılarda gencinden kıdemlisine herkesin görüşlerini alıp birçok kararı fakülte kurullarında aldığını belirtmiş̧ir. Bununla birlikte akademik personelin odalarına sıklıkla gidip, kapılarını tıklatıp konuşacağı şeyleri direkt söyleyerek kişilerden geri dönüt almaya çalıştı̆ı̆ını da sözlerine eklemiştir (“3. Fakülte Dekanı” str 14-17, 125-127). Bu tema altında son dekan insanların güvenlerini kazanmak için, hangi yaştan olursa olsun takdir edilmekten hoşlandıklarını belirtmiş ve bu amaçla yılbaşında çalışanlara meslekteki kıdemlerine göre bir teşekkür töreni düzenlediklerinden bahsetmiştir. Kendisiyle ilgili kutlama yapılmasında utanıp, çekinse de doğum gününde fakülte kurulunda sürpriz kutlama yapılması ve komisyon çalışmalarında o olduğu için görevi kabul ettiğini söyleyen çalışanlar, 4. dekanı mutlu eden ve ilişkilerde güvene işaret eden referanslar olarak tespit edilmiştir (“4. Fakülte Dekanı” str 288-291, 344-346, 373-376, 382).

Otantikliğin sinerji etkisini çözümleyen ikinci veri kodu yetki vererek çalışanlarla ilişkileri güçlendirme temasıdır ve toplam 15 referanstan oluşmaktadır. Burada 1., 2. ve 4. fakülteden 4'er referans gelirken 3. fakülteden 3 tane referans cümlesi alınmıştır. Görüşme yapılan 1. fakülte dekanı, yetki verdiği çalışanlardan kendi fikirlerine ters bile olsa görüş istediğini belirterek, ilişkilerini güçlendirdiğini, kim iyi biliyorsa işi onun yapmasını uygun gördüğünü, çalışma arkadaşlarına sorumluluk verdikten sonra onlara güvendiğini ve işin arkasında bezdirici bir kontrol mekanizması kurmadığını söylemiştir (“1. Fakülte Dekanı” str 40, 82-87). 2. Dekan genç çalışma arkadaşlarına normalde verilmeyen yetkiler vererek, kendi görüşüne ters olsa da ısrarla alternatif fikirleri duymayı tercih ettiğinden ve dekan yardımcılarıyla uyumlu çalışma ortamından bahsederek, kurulan ilişkilere dair referansları dile getirmiş̧ir (“2. Fakülte Dekanı” str 141, 151-154, 221-224). Görüşmede 3. Dekan toplumsal değer yargılarıyla çatışmadığı sürece çalışanların değerlerini önemsediğini ifade ederken, 
aynı zamanda oluşturduğu kurul ve komisyonlara çalışan herkesi zorunluluk olmaksızın davet edip, dahil ederek ilişkileri güçlendirmeye çalıştığını belirtmiştir (“3. Fakülte Dekanı” str 48-50, 96-102 ). Son olarak araştırma kapsamında 4. dekandan gelen yanıtlar ise; kurumda birlikte karar alma kültürünün yaygın olduğu, herkesin gerek informal, gerekse formal toplantılarda fikirlerini rahatılıkla ifade edebildiği ve fakülte içerisindeki her bölümün kendi meslek disiplininin ayrı olması nedeniyle iç işlerine karışılmadığı söylemleridir. Tüm bu ifadeler çalışanlarla ilişkileri güçlendirme adına 4. dekanın yaklaşımlarına referans olmaktadır (“4. Fakülte Dekanı” str 9-10, 38-43, 125-127).

Otantik liderliğin sinerjiye etkisi kod başlığı altında ele alınacak diğer bir tema daha fazla risk alma davranışının görülme durumudur. Bu tema altında toplam 3 referans bulunmaktadır. 3. fakülteden hiç referans çıkmazken, 1., 2. ve 4. fakülte dekanlarından birer tane referans tespit edilmiştir. Görüşme yapılan ve referans alınan 1. dekan, herkes fikrini söylesin, yanlış bile olsa o yanlışın içinde dahi doğrular olduğuna inanırım diyerek kendisinin risk alabileceğini belirtmiştir ("1. Fakülte Dekanı” str 13-14). Bu konuda görüş belirten 2. dekan fakültelerde büyük ve kıdemli hocaları yeri geldiğinde susturup, genç asistanlardan fikir isteyerek normalde yapılmayan ve riskli bulunan uygulamalara gittiğinin altını çizmiştir (“2. Fakülte Dekanı str 42-43). 4. Dekan ise fakültelerinin akredite sürecindeki raporlandırma aşamasında her bölümü bağımsız bırakarak risk aldıklarını, ancak sonrasında denetleyici kurumdan özgünlük, etkinlik ve farkındalıkla ilgili takdir topladıklarını ifade etmiştir ("4. Fakülte Dekanı" str 116-124).

Otantikliğin sinerjiye etkisi kod başlı̆ı altındaki son temada, otantik liderin ve çalışanların örgütsel başarısı sorgulanmaktadır. Bu tema altında toplanan 9 referanstan 1'i ilk fakülteye, 3’ü 2. fakülteye, 2'si 3. fakülteye ve son olarak 3 tanesi de 4. fakülteye aittir. Araştırma kapsamında görüşme yapılan 1. dekan başarıya dair çalışanların kendisinden memnun olup olmadı̆̆ına ilişkin soru karşısında emin olamazken, bu konuda daha önce yapılan bir araştırmada olumsuz yanıtların da geldiğini, dolayısıyla net bir şey söyleyemeyeceğini dile getirmiştir (“1.Fakülte Dekanı” str 62-63). Referans alınan 2. dekan kendisinin artı özelliklerinin insanlar tarafından çok değerlendirilemediğini, kişilerin doğası gereği yüzde yüz herkesi memnun etme şansının olmadığını ve bu nedenle kendisiyle ilgili olumlu ya da olumsuz görüşlerin olabileceğini ifade etmiştir ("2. Fakülte Dekanı" str 138-139, 227-230). Görüşme yapılan 3. dekan kendisinin de çalışanların görüşünü merak etmesi sebebiyle ara ara onları yokladığını belirtmiş ve kurumdaki herkesin gereksinmelerine göre bir yönetim tarzı sergilemenin kolay olmadığını sözlerine eklemiştir. Ayrıca çalışanların hepsi olmasa da yarıdan fazlasının kendiyle ilgili memnuniyete sahip olduğu düşüncesini ifade etmiştir ("3. Fakülte Dekanı" str 131-132, 137-139). Başarı teması altında görüş belirten 4. dekan, ilk olarak sadece o olduğu için kurumda görev almayı kabul eden çalışanlardan bahsetmiştir. Tüm kuruma bakıldığında kendisini sevenler olabileceği gibi, sevmeyenlerde olabileceğini düşünen dekan, sonuç olarak fakültedeki uzun görev yıllarını düşündüğünde çoğunluğun kendisiyle ilgili memnuniyete sahip olduğu kanısında olduğunu dile getirmiştir (“4. Fakülte Dekanı” str 249-253, 347-349).

Ana veri kodlarından üçüncüsü otantik liderliğin özellikleridir. Bu tema altında altı özellik bulunmaktadır. Bunlardan ilki otantik liderin aklın yanı sıra, merhamet ve tutku gibi duygularla hareket etmesidir. Bu başlık altında tespit edilen toplam 7 referans vardır. Bunlardan 2'si, 1. fakülteye, 3 


\section{Güzin KIYIK KICIR | Didem PAŞAOĞLU}

tanesi 2. fakülteye, 1'er tanesi ise 3. ve 4. fakülteye aittir. Görüşme yapılan 1. dekan acı gerçekleri paylaşma noktasındaki hassasiyetinden bahsederken içindeki merhamet duygusuna ilişkin ipuçları vermiştir. Bu noktada söylemesi gereken konuları çalışanlarına bazen söyleyemediğini ya da zaman zaman bir durumu direkt anlatamadığını da ifade etmiştir ("1. Fakülte Dekanı str 6, 16). Araştırma kapsamında görüşülen 2. dekan, sıkıntılı durumları paylaşırken çalışanlarını teselli edip, yüreklendirdiğini belirtmiş, onlara sarılarak ya da omuzlarına dokunarak gerçekleri anlattığını, böylece çalışanlarını rahatlattığını söyleyerek içindeki merhamet duygusunu dile getirmiştir ("2. Fakülte Dekanı” str 50-52, 61-63, 65-67). Görüşme yapılan 3. dekan acı gerçekleri acıtmadan söylerim diyerek kendisinin bakış açısını anlatmıştır (“3. Fakülte Dekanı”, str 21). 4. Dekan ise sıkıntılı durumları, çalışanları kırıp, incitmeden söylemenin kendisi için doğru bir üslup olduğunu ifade etmiştir ("4. Fakülte Dekanı" str 55-57).

Üçüncü ana tema altında ele alınan, otantik lidere ait bir diğer özellik, liderin kendine karşı dürüst oluşu ve başkalarına uymak amaçlı kişiliğinden ödün vermemesidir. Bu başlıkla ilgili gelen referans sayısı toplam 13'tür. Bunların 4'ü, 1. fakülteye, 2'si, 2. fakülteye, 3 tanesi 3. fakülteye ve kalan 4'ü ise 4. fakülteye aittir. Görüşme yapılan 1. dekan, sorunlu durumlarda ilk etapta sabrettiğini, uzun bir süre düşündükten sonra zor olan kararları dahi uygulayabildiğini ifade ederken, zaman zaman kurumun menfaatleri doğrultusunda yapmam dediğiniz şeyleri dahi yapabiliyorsunuz diyerek, kişiliğiyle ilgili ödünler verebildiğini ifade etmiştir. Ayrıca birden çok kişi karşıt fikri savunuyorsa, her şeyi kendisinin en doğru bildiği gibi bir bakış açısıyla duruma yaklaşmadığının da altını çizmiştir ("1. Fakülte Dekanı" str 23-25, 37-38, 43-45, 74-75). Görüşme yapılan 2. dekan bir konuda karar verdiği zaman ailesi dahil hiç kimsenin kararını değiştiremeyeceğini ve bu konuda oldukça tutarlı olduğunu dile getirerek ödün vermediğini açıklamıştır. Kararları zaman zaman aykırı gelse de fikirlerinden vazgeçmemesini de 'kargalar sürüyle, kartallar yalnız uçar' söylemiyle desteklemiştir (“2. Fakülte Dekanı” str 96-97, 107-108). Araştırmada görüşülen 3. fakülte dekanı, kararlarında azami ölçüde tutarlı olmaya çalıştığını, ancak bir yönetici olarak zaman zaman kesin olamadığı ve yumuşadığını söylemiştir. Bu konuda ayrıca inandığı değerler ile kurum kimliği çeliştiğinde orta yolu bulmaya çalıştığını ve hukuk kuralları ile kurumsal işleyişe aykırı olmadığı sürece farklı fikirlere destek verebileceğini dile getirmiştir (“3. Fakülte Dekanı” str 36-38, 39-40, 60-63). Bu tema altında 4. dekan ise; bazen hızlı karar alınması gereken durumlarda geri adım atıp, yeni kararlar verme esnekliğine sahip olduğunu ifade etmiştir (“4. Fakülte Dekanı” str 89-91, 191, 264-269).

İçerik analizi kapsamında ele alınan bir diğer tema, otantik liderin davranışlarının temelini değer yargıları ve kanaatlerin oluşturup oluşturmadığını sorgulamaktadır. Bu başlık altında tespit edilen toplam 7 referans cümlesi vardır. Bunların 1'i, ilk fakülteye, 2'si, 2. fakülteye, 3'ü, 3. fakülteye ve son olarak 1 tanesi de, 4'ü fakülteye aittir. Görüşme yapılan 1 . dekan kararlarını değer yargılarının oluşturup oluşturmadığı konusundaki sorulara genellikle evet yanıtını verirken, 4 . dekan bu konuda daha net bir şekilde hiç düşünmeden kesinlikle evet yanıtını vermiştir ("1. Fakülte Dekanı" str 27, “4. Fakülte Dekanı” str 83). Araştırma kapsamında görüşme yapılan 2. dekan zaman zaman aykırı bulunsa da inandığı değerlere göre iş yaptığını ve kararlar aldığını söylemiştir ("2. Fakülte 
Dekanı" str 89-91). 3. Dekan, 45 yıllık hayatında edine geldiği değer yargılarının kararlarında etkili olduğunu belirtmiş ve yakın zamanda düzenlenen bir raporda bu anlamda zor bir karar verişini duruma örnek göstermiştir. 3. Dekanın bu konuda istisna olarak belirttiği durumlar ise kurum kimliğiyle çelişme ve akla yatkın fikir paylaşımlarındaki esneme halleridir ("3. Fakülte Dekanı” str 38-42, 44-46, 83-84).

3. ana veri kodu altındaki diğer bir başlık, otantik liderin statü ve kişisel çıkarlar yerine sosyal çıkarlarla güdülenmesidir. Bu tema altında yalnızca 2. fakülteden referans tespit edilmiştir. Dekan arkadaşlarıyla vakit geçirmeye zaman ayırarak, enerji depoladığını belirtmek suretiyle sosyal ilişkilere verdiği önemi vurgulamıştır. Ayrıca değerinin çevresindekilerce çok fazla bilinmemesinden dolayı duyduğu kaygıyı ifade ederken sosyal dinamiklerden etkilendiğini bir kez daha belirtmiştir ("2. Fakülte Dekanı" str 138-139, 274-279).

Otantik liderliğin bir diğer özelliği olan insanlara hizmet etme ve çalışanları güçlendirme başlığı araştırma kapsamındaki diğer bir temadır. Bu tema altında iki dekandan, toplam 5 referans tespit edilmiştir. Bunların 4'ü, 2. fakülteye, 1 tanesi ise 3. fakülteye aittir. Görüşme yapılan 2. dekan, fakülte açısından alınacak kararlarda tek başına hareket etmediğini, zorunluluğu olmamasına rağmen o konuyla ilgili tüm akademisyenlerin görüşlerini isteyip, karara vardığını belirterek, çalışanları güçlendirme çabasını ifade etmiştir. Hem öğrencilere, hem de akademisyenlere sürekli olarak haklarını savunmaları ve gerektiğinde seslerini çıkarmaları mesajı verdiğini sözlerine eklemiştir. 2. Dekan ayrıca görevleri içerisinde olmamasına rağmen dekanlar konseyine ve fakülte kuruluna konu götürme çabası ve zaman zaman sağlığı müsaade etmese de rapor kullanmadan çalışma gayreti ile hizmet bilinci konusundaki hassasiyetini de dile getirmiştir ("2.Fakülte Dekanı" str 171-176, 176178, 250-251). 3. fakülte dekanı ise, personelinden gerekli olduğu durumlarda görüş istediğini ve olumlu-olumsuz birçok düşünceden destek alarak fakülte ile ilgili karar ve raporlarda bunları kullandığını ifade etmiştir (“3. Fakülte Dekanı” str 96-102).

Araştırma kapsamında belirlenen temalar içindeki son başlık otantik liderin doğuştan değil de sonradan geliştirmeye çalıştığı özelliklerle ilgilidir. Bu temada üç dekandan toplam 6 referans alınmıştır. Illk fakülte dekanının görüş belirtmediği bu başlıkta 2. fakülte dekanından 2 referans, 3. fakülteden 1 ve son olarak 4. fakülte dekanından 3 referans alınmıştır. Görüşme yapılan 2. dekan ilk anda hatasını kabul edemese de zamanla çevresinde güvendiği insanlarla konuştuktan sonra geri adım atmayı öğrendiğini ve hatasını mutlaka gidip düzelttiğini belirtmiştir (“2. Fakülte Dekanı” str 11-15). Sonradan geliştirilen liderlik özellikleri teması altında görüş belirten 3. fakülte dekanı, daha önce yaptığı idari görevlerden elde ettiği tecrübelerin kendisini çok geliştirdiğini ve zamanla çok şey kazandığını ifade etmiştir (“3. Fakülte Dekanı” str 32-34). Son yani, 4. dekan ise özellikle fakülte içerisindeki akreditasyon süreçlerinde çok şey öğrendiğini söylemiş ve zamanla yaşadığı gelişimin altını çizmiştir (“4. Fakülte Dekanı” str 264).

\section{Yorum ve Öneriler}

Bulgulara bakıldığında temalara göre en çok referansın tespit edildiği fakülte dekanları sırasıyla; 2., 4. 3. ve 1. dekanlardır. Bu noktada en çok referansı alan ilk iki dekanın kadın yöneticiler olma- 


\section{Güzin KIYIK KICIR | Didem PAŞAOĞLU}

Sı ve fen bilimlerine ait fakülte dekanlarının temalarla daha çok ilişkilendirilen yanıtlar verdiği görülmektedir. Sosyal bilimlere ait iki fakültenin bu anlamda daha az referans sayısıyla araştırmada yer aldığı söylenebilir. Dağılımlara ilişkin sayı ve yüzdeleri Tablo 3'de görmek mümkündür.

Tablo 3. Referans Dağılımları

\begin{tabular}{lccrrr}
\hline \hline & $\begin{array}{r}\text { Cinsiyet } \\
\text { Durumu }\end{array}$ & $\begin{array}{r}\text { Bilimsel } \\
\text { Alan }\end{array}$ & $\begin{array}{r}\text { Toplam } \\
\text { Referans }\end{array}$ & $\begin{array}{r}\text { Ana Tema } \\
\text { Başlıklarına } \\
\text { Göre Referans } \\
\text { Dağılımı }\end{array}$ & $\begin{array}{r}\text { Yüzdesel } \\
\text { Dağılım }\end{array}$ \\
\hline 1. Fakülte Dekanı & Erkek & Sosyal Bilimler & 27 & $11-9-7$ & $\% 17$ \\
2. Fakülte Dekanı & Kadın & Doğa Bilimleri & 57 & $36-12-9$ & $\% 35$ \\
3. Fakülte Dekanı & Erkek & Sosyal Bilimler & 36 & $22-7-7$ & $\% 22$ \\
4. Fakülte Dekanı & Kadın & Fen Bilimleri & 43 & $21-16-6$ & $\% 26$ \\
\hline
\end{tabular}

Araştırmada tüm temalar içinde en çok referans alan başlık otantik liderlik unsurlarından biri olan ilişkilerde şeffaflık temasıdır. En az referans ise liderlik özellikleri ana başlığı altındaki statü ve kişisel çıkarlar yerine sosyal çıkarlarla güdülenme özelliğidir. Bu tema aynı zamanda tüm çalışma içerisinde en az sayıda dekandan referans alan tema olmuştur.

Araştırma kapsamında görüşme yapılan dekanları otantik liderlik ile ilgili sırayla değerlendirdiğimizde en az referansın 1. dekanda tespit edildiği görülmektedir. Temalara bakıldığında öncelikle 1. dekanın öz farkındalığının, katıımcı yönetim anlayışına olan yatkınlık konusunda olduğu dikkati çekmiştir. Bilgiyi dengeli ve tarafsız kullanma teması altında da benzer şekilde çoğunluğun görüşünü önemseyen duruşu ve tek taraflı karar alması gerektiğinde dahi karşıt görüşleri dikkate alma isteği, katılımcı bakış açısını destekleyen göstergelerdendir. Bu noktada 1. dekanın kararlarını vermeden önce her zaman araştırma yapamayan ve çevresindeki insanlara yetki vererek, çoğunluğun istediği kararlara yönelen bir liderlik anlayışı benimsediği söylenebilir. İçselleştirilmiş ahlak anlayışı konusunda hatalarını kabul etme erdemine sahip olan 1. dekan, zaman zaman kurumsal sorumluluğundan dolayı başkalarının hatalarını dahi üstlenebildiğini ifade ederek otantik liderlerde bulunması gereken vicdani duygulara ve bunun yanı sıra gerektiğinde risk alabilme özelliğine dair ipuçları vermiştir. Ayrıca yanlış bile olsa herkesin fikrini söylemesini desteklemesi de, 1. dekanın risk alma eğilimine ve çalışanların gelişimi ve iyiliği adına atılan adımlara örnek gösterilebilir. ilişkilerde şeffafIık noktasında acı gerçekleri endirekt olarak söylemeyi tercih eden, kızgınlığını son noktaya kadar yansıtmayan, kişisel hayattaki sorunlarını iş yerine taşımayan 1. dekan, \% 100 şeffaf bir iletişim yerine daha kapalı bir yönetim tarzını benimsemektedir. Ancak etik açıdan sıkıntıı konularda normalde olmadığı kadar sert kararlar da alabildiğini görüşmelerde ifade etmiştir. Çalışanlar hata yaptığında onları yalnız bırakmayan ilk dekan, ayrıca pek çok çalışanının sırf yönetici olarak kendisine zarar gelmemesi için özverili ve düzgün çalıştığını söyleyerek, aradaki güven ilişkisine dikkat çekmiştir. Takipçilerin saygısını kazanmak anlamında bu örnek otantik liderlik için de önemli bir vurgudur. 
Personeline gerçek anlamda yetki verip baskıcı bir kontrol mekanizması oluşturmayan 1. fakülte dekanı, aynı zamanda yetki verme hevesi ve çalışanlarla ilişkileri güçlendirme konularında da olumlu değerlendirilebilir. Kurum çıkarları doğrultusunda zaman zaman yapmam dediği şeyleri yaparak bazen kendi kişiliğinden ödünler verebildiğini söyleyen ilk dekanın, son olarak takipçilerinin kendisi hakkındaki memnuniyetine ilişkin verdiği emin olmayan yanıtlar, otantik liderlik algısı konusunda olumsuz olarak değerlendirilen ifadelerdendir.

Bulguları değerlendirme aşamasında ele alınan 2. görüşmeci aynı zamanda, araştırmada en çok referansın tespit edildiği kişidir. Çalışmada öncelikle, 2. dekanın açık bir iletişim biçimini sevdiği ve kararlarıyla hayatında net bir duruş sergileme konusunda öz farkındalığa sahip olduğu ortaya çıkmıştır. Araştırmadan ve incelemeden karar almayan 2. dekan, ayrıca herkesin görev tanımlarını tek tek belirleyerek objektif değerlendirme açısından kendine uygun bir ortam hazırlamıştır. Kişisel olarak insanlarla problem yaşamayı sevmediği için insan değil, iş odaklı yaklaşımı benimseyen 2 . fakülte dekanının, etik sıkıntılar yaşamamak adına görev tanımları ve standartları en başta belirleyerek çalışanlarına bu şekilde yaklaştığı görülmektedir. Düşüncelerini söyleme konusunda açık iletişimi tercih etse de, sevmediği kişilerle iş yapması gerektiğinde profesyonellik gereği iletişim kurduğunu belirten 2. dekan, iletişimde şeffaflık noktasında zaman zaman istisnai ve kapalı bir tutum sergileyebilmektedir. Üst düzey kararları anında mail, mesaj gibi teknolojik araçlarla tüm çalışanlarına duyurmayı tercih eden, fakülteyle ilgili yapılan icraatları sürekli raporlayarak çalışanlarına sunan dekan, sadece sağlık problemleri gibi kişisel nedenlerde kendisine ilişkin bilgileri paylaşmamayı tercih etmektedir. Gençlere söz verme ve onlardan fikir isteme noktasında teşvik edici yaklaşımları 2. dekanın katılımcı liderlik anlayışı için önemli göstergelerden biridir. Bu noktada 2. dekanın büyük hocaları susturup, gençlerden fikir isteme çabası, kendi fikrine karşı bile olsa ısrarla takipçilerinin fikirlerini sorması, çalışanlarla lider arasındaki ilişkileri güçlendirici ve karşılıkı güveni pekiştiren bir atmosfer için hazırlayıcı unsurlar olarak değerlendirilebilir. Bu yaklaşım aynı zamanda otantik liderliği pekiştiren uygulamalar olarak da görülmektedir. Sıkıntılı konuları paylaşma konusuna gelindiğinde genellikle vücut dilini kullanarak teselli eden bir tarz ve hassasiyetle kişileri bilgilendirmeyi tercih eden dekan, kişiyi bir kenara çekip konuşarak, onu önemsediğini hissettiren bir anlayışla yaklaştığını belirtmiştir. Karar noktasında öncelikle iyice araştırdığı ve tüm fikirlere açık olduğu için bir karar verdikten sonra asla geriye dönmediği söyleyen 2. dekan, bu anlamda ödün vermeyen çizgisiyle ilgili de fikir vermiştir. Otantik liderlikle ilgili en çok referans cümlesinin tespit edildiği fakülte dekanı olmasına rağmen, takipçilerinin \%100 memnuniyetine sahip olduğunu düşünmeyen 2. dekan, herkesi mutlu etmenin mümkün olmadığına, ancak çoğunluğa ulaştığına inanmaktadır. Kendi görevi olmamasına rağmen ekstra yeni işler tanımlayıp, üstlendiğini ifade eden 2. fakülte dekanı, böylece insanlara hizmet etme konusundaki isteğinden bahsetmiştir. Zaman içinde hatalarını kabullenmeyi öğrendiğini ve geri adım atmayı başardığını söyleyen dekan bu cümlelerle otantik lidere ait zamanla geliştirilen yanlara ilişkin de ipuçları vermiştir. Gezmeyi, arkadaşlarına zaman ayırmayı, sosyalleşmeyi çok sevdiğini, hayata ilişkin her cümlesinde ifade eden 2. dekan, statü ve kişisel çıkarların yanı sıra sosyal çıkarlara da önem veren bir profil çizmektedir. Bu anlamda dekanın hayatla ilgili ödün vermeyen net duruşundan dolayı yalnız kalışından bahsetmesi, kendi değerinin çok bilinmediğini düşünmesi, herkesi memnun edemeyeceğine inanması, yöne- 


\section{Güzin KIYIK KICIR | Didem PAŞAOĞLU}

timdeki çalışma arkadaşlarıyla olan uyumlu ilişkilerinin altını çizmesi, genç meslektaşlarına farklı gruplarla görüşüp, çevrelerini genişletmelerini tavsiye etmesi gibi bulgular sosyal çıkarları önemsediğine dair işaretler olarak kabul edilebilir.

Görüşme yapılan 3. dekana ait bulgular incelendiğinde, yönetici olmanın zorluklarını bilme ve zaman zaman duygularını (kızgınlık, kırgınlık, hayal kırıklı̆ı vb.) kontrol ederken yaşadığı güçlüklerle ilgili dekanın kendini tanıma bilincine sahip olduğu ortaya çıkmışır. Karar vermeden önce ya da raporlamalarda araştırma yapan, fikir alan, karşıt görüşleri isteyen 3. dekan, tıpkı 2. dekanda olduğu gibi bilgiyi tarafsız değerlendirebilme adına çok yönlü kaynaklardan beslenmeyi tercih etmektedir. İnsanlara haksızlık yapmamak için herkese iş odaklı yaklaşmaya çalıştığını dile getiren dekan, içselleştirilmiş ahlak anlayışı konusundaki hassasiyetini de bu şekilde dile getirmiştir. İnsanları ayağına beklemek yerine direkt odalarına giderek iletişim kurmayı tercih eden 3. fakülte dekanı, iletişim biçimi anlamında çoğunlukla danışan, takipçilerine ilk adımı atmaktan çekinmeyen, hata yaptığında tüm fakülte üzerinden olmasa da, olay üzerinde düzeltme yapabilen bir şeffaflığa sahiptir. Ancak kızgınlıklarını ve hayatıyla ilgili özel durumları takipçilerine yansıtmaması, kişisel olarak sevmediği insanlarla iş gereği konuşması, 3. dekanı şeffaflık anlamında sınırlandırıı durumlardır. Zorunlu olmamasına rağmen fakülte hocalarının görüşlerini isteyen 3. dekan katılımcı bir yaklaşımla hareket etmekte, ancak ortaya atılan fikirler toplumsal değer ve fakülte çıkarlarına ters düşmediği sürece çalışanlarını destekleyebilmektedir. Dolayısıyla çalışanları güçlendirme isteği olsa da aradaki güvene dayalı yapıyı oluşturmada dekanı sınılandıran durumlarda söz konusudur. Otantik liderin risk alma davranışı göstermesi konusundaki temada 3. dekandan hiç referans bulunamaması da bu düşünceyi destekleyici niteliktedir. İlk iki dekanda olduğu gibi çalışanların kendisiyle ilgili memnuniyetinden emin olamayan ancak çoğunluğun olumlu düşüncelere sahip olduğuna inanan 3. fakülte dekanı örgütsel başarı konusunda bu anlamda yüzde yüzlük bir başarıdan söz etmemiştir. Acıtacak durumları acıtmadan konuşmaya gayret eden bir üslup tercih ederek, iş arkadaşlarına olabildiğince merhametli yaklaşmaya çalışığının sinyallerini veren 3. dekan, zaman zaman çok zor kararlar alabildiğini ve kişisel değerlerinden ödün vermesi gerektiği durumlar yaşadığının da altını çizmiştir. Bu hallerin genellikle fakülte yararına olan kararlarda ortaya çıktığını söyleyen dekan, verdiği yanıtla otantik lider özellikleri içerisinde yer alan kişisel duruş ve değerlerinden ödün vermeme konusunda, başkalarına uyma davranışı gösterme eğiliminin sinyallerini vermiştir. Var olan özelliklerine yenilerini ekleyebilme yeterliliği konusunda ise 3. dekanın, bu zamana kadar ki idari görevlerinin ve yaşam tecrübesinin kendisine çok şey kattığını belirtmesi, otantik liderlikte bahsi geçen gelişime açık profile işaret etmektedir.

Görüşme yapılan son dekana gelindiğinde 4. dekanın, klasik yetki-sorumluluk zincirini uygulayan bir stilin dışında hareket ettiği ve uygulamada direkt yer alarak, takipçilerine bizzat örnek olma farkındalığına sahip olduğu görülmüştür. Bu anlamda otantik liderliğin yol gösterici kimliğiyle örtüşen bir tarz da ortaya çıkmaktadır. Son dekan, herkesi dinleyip, empati yapsa da, en sonunda kendi kurallarını koyan ve kırmız çizgileri net olan bir yönetici olma özelliğine sahiptir. Genellikle araştırıp, iyice düşündükten sonra kararlar almayı tercih ettiğini söyleyen 4. fakülte dekanı, sadece hızlı 
olunması gereken durumlarda tüm tarafları dinlemeden ve iyice araştırmadan karar alıp riske girdiğini istisna olarak belirtmiştir. Etik konusuna faaliyet ve kararlarda öncelikli olarak dikkat etmeye çalıştığını söyleyen dekan ayrıca hatalarından ders çıkarabilmeyi önemsediğini söyleyerek içselleştirilmiş ahlak anlayışı konusundaki değer yargılarıyla ilgili de ipuçları vermiştir. iliş̧kilerde şeffaflık noktasına gelindiğinde 4. dekanın, örgütünde açık kapı politikasını uyguladığı, lafı dolandırmadan net iletişim kurmayı sevdiği, çalışan ve öğrencilerle periyodik toplantılar yaparak istek ve beklentileri yakalamaya çalıştığı görülmüştür. Bunlara ek olarak iletişim konusunda uzmanlardan destek alındığı, fakülteye memnuniyet anketleri uygulandığı, iletişime dair etkinlikler düzenlendiği belirtilerek ilişkileri güçlendirme konusundaki çabalar ifade edilmiştir. Çalışanlarıyla bağları güçlendirmek ve onların güvenlerini kazanmak adına, kadro türü gözetmeksizin kıdeme bağlı olarak onurlandırııı toplantılar düzenlediklerini söyleyen son dekanın bu çabası vefa ve takdir kaynaklı örgütsel bağıılı̆ı artırıcı uygulamalar anlamında olumlu değerlendirilebilir. Sadece o, yapılan işin başında olduğu için görev almayı kabul ettiğini söyleyen çalışanlar da bu değerlendirmeleri destekleyen ve lidere ilişkin olumlu düşüncelere işaret eden göstergelerdendir. Akreditasyon gibi kapsamlı süreçlerde fakülte içindeki her meslek disiplinine saygı duyup, işlerine karışmayarak, rapor hazırlama noktasında onları özgür bırakan 4. dekanın, risk alarak, özgün, kendini tekrar etmeyen ve takdir toplayan bir işe imza atması, otantik liderlik ve sinerji etkisini inceleyen risk alma eğilimine ilişkin de önemli bir bulgu olarak kabul edilebilir. Iletişim kurarken net olan ve böylece iş süreçlerinde zaman kaybetmemeye çalıştığını belirten 4. dekan, acı ve sıkıntılı konularda incitmeden ifade etmenin ve üslubun öneminden bahsederek insanlara bazı durumlarda merhametle yaklaştığının alt mesajını vermiştir. Uzun yıllar süren idarecilik hayatından algıladığı kadarıyla pek çok kişini kendisinden memnun olduğunu düşünen dekan, hizmet yıllarında edindiği tecrübelerle hem kişiliği, hem de yöneticilik yaklaşımı anlamında gelişim yaşadığını da ifade etmiştir. Bu ifade, doğuştan gelen özelliklere sonradan yenilerini ekleyebilen otantik liderliğe ilişkin önemli bir gösterge olarak kabul edilebilir. Kararlarını kesinlikle değer yargılarına göre verdiğini belirten, kendisiyle paylaşılmadığı sürece kimsenin özel hayatıyla ilgilenmeyen, bireysel farklılıkları anlamaya çalışan ve buna değer veren 4. dekanın bu özellikleri, takipçilerin saygısını kazanmada etkili olabilecek özellikler arasında görülmektedir.

Değerlendirmeler sonucunda en çok referansı alan 2. dekan ve en az referansı alan 1. dekanın otantik liderliğe en yakın ve en uzak liderler oldukları ancak, bulgular derinlemesine incelendiğinde araştırmadaki temaların içeriği açısından 4. dekandan gelen bulguların otantik liderlikle daha çok örtüştüğü söylenebilir. 4. dekan aynı zamanda çalışmada en çok referansı alan ikinci dekan olma özelliğindedir. Görüşme yapılan tüm dekanların yanıtlarına bakıldığında hepsinin otantik liderlikle kesişen, farklılaşan, gerçekten benzeyen ya da benziyormuş gibi duran yanları olduğu görülmüştür. Örneklem grubu içerisinde otantik liderliğe, referans sayısı bakımından 2., içerik olarak ise 4. dekanın yakın olduğu ifade edilebilir. 2. ve 4. dekanlar aynı zamanda dört kişilik örneklem grubunun kadın katılımcılarıdır. Moir ve Jessel (2002: 35-37), beynin belirli bir cinsiyete göre geliştiğini öne sürmekte ve cinsler arasındaki davranış ve tutum farklılaşmalarını hormonal tesirlere bağlamaktadır. Beyin kaynaklı doğuştan gelen farklııkların, kadınların ve erkeklerin olguları başka türlü algılayıp, sıralayıp, değerlendirip, başka türlü tepki vermelerine sebep olduğunu ifade etmektedir. So- 


\section{Güzin KIYIK KICIR | Didem PAŞAOĞLU}

nuçta algılanan iki farklı dünya ile kadınların ve erkeklerin farklı tavır ve tutumlara sahip olduklarını söylemektedir (Ersoy, 2009). Bu bağlamda araştırma örneklemi kapsamında akademik platformda kadınların otantik liderlik yaklaşımına daha yatkın olduğu ve otantik liderliğe ilişkin özelliklerin gelişimi anlamında gruptaki erkek katılımcılarına göre daha avantajlı bir konuma sahip oldukları söylenebilir. Bu farklılıklar aynı zamanda kültürel, toplumsal ve sosyal etkilerden de kaynaklanabilmektedir. Anaerkil göçebe sistemden, yerleşik ataerkil yapıya doğru dönüşüm yaşayan Türk kültüründe kadının rol ve görevleri değişse de gücü ve yetenekleri önemini korumaktadır. Bu düşünceye paralel olarak örneklem kapsamında otantik liderliğe kadınlar daha uyumlu bir profil çizmiştir. Özellikle şeffaflık, sinerjiyle ilişkili güven oluşturma ve gelişime açık olma temalarında kadın ve erkek dekanlar arasındaki farklııılar öne çıkmaktadır.

Bilim alanları açısından örneklem grubundan çıkan sonuçlara bakıldığında referans yoğunluğuna sahip 2. ve 4. fakültelerin fen ve doğa bilimlerinden çıktığı görülmektedir. Fen bilimleri insanların maddesel çevresini denetlemek ve değiştirmek amacıyla geliştirdiği teknolojik bilgileri kapsarken, doğa bilimleri gözlem nesnesi doğa olan ve sürekli tekrarlanan olayları inceler ve bu anlamda sosyal bilimlerden ayrılır. Konusu insan ve insan ilişkileri olan sosyal bilimlerden gelen 1 . ve 3 . fakültelerde görev alan dekanların beşeri bir olguda olsa liderlik konusuna örneklem grubundaki diğer iki dekana göre daha uzak kalması çalışmanın dikkat çeken sonuçlarından olmuştur.

Dekanları sırayla incelediğimizde; araştırmada en az referansın tespit edildiği 1. dekan, otantik liderliğe en uzak yönetici olarak görülse de, görüşme sorularına verilen yanıtlardan otantiklikten ziyade, koç tipi liderlik anlayışına daha yakın bir profil çizmektedir. Bu anlamda 1. dekan güvene dayalı, babacan, ekibine yetki verip, hatalarında arkalarında duran bir teknik direktör görüntüsüne sahiptir. 2. Dekanda ise otantik liderlik özelliklerini baskılayan doğuştan getirilen özellikler dikkati çekmektedir. Bu anlamda özellikler teorisi ve karizmatik liderlik yaklaşımının 2. dekan üzerindeki etkisinden ve bu etkinin otantiklik algısında kaymalara neden olduğundan söz edilebilir. Araştırma kapsamında görüşme yapılan 3. dekan, gerek iletişim çabaları, gerekse katılımcı yönetim anlayışıyla otantik liderliğe vurgu yapan pek çok özelliğe sahiptir. Ancak fakülte kararlarında ödün verme ve uyma davranışı gösterme eğilimi, otantikliği baskılayan nedenler arasında yer almaktadır. İlk üç dekanın her birinde otantik liderlik etkileri yakalanmıştır. Ancak kavrama içerik anlamında en yakın görülen dekan 4. dekandır. Uygulanan açık iletişim politikaları, yetki verme ve sonucunda risk alarak çalışanları güçlendirme gayretleri, vefa, takdir gibi duygularla kişilerin kurumla bağlarını güçlendirme etkinlikleri ve insanlara yol göstermek için bizzat örnek olma çabalarıyla kavramsal olarak otantikliğe en yakın profili 4. dekan çizmiştir. Bunu destekleyen en önemli gösterge ise çalışanların düşünce ve duygularını ifade eden dekana ait referans cümleleridir.

Akademik platform için destekleyici ve güçlendirici olarak görülen otantik liderlik konusunda araştırmaya konu olan dekanlar için öneriler söz konusudur. Öncelikle 1. Dekanın, kararlarında bilgiyi dengeli alma ve tarafsı değerlendirebilme becerisini iyileştirmesi, risk alma davranışına buradan hareketle gitmesi, sosyal çıkarların önceliğini yükseltmesi, öz farkındalık seviyesini artırıp ona paralel olarak kişisel ve örgütsel gelişime daha açık bir profil çizmesi yerinde olacaktır. Ayrıca 
kendinden ödün verme noktasında da daha net bir duruş sergilemesi, 1. dekanı otantikliğe yaklaştıracak öneriler arasındadır. 2. Dekanın doğuştan getirdiği baskın özellikler, onun üstünlükleri halini aldığı için otantik liderlikle de zaman zaman örtüşen bu güçlü özelliklerin değiştirilmesini tavsiye etmek pek sağlıklı değildir. Ancak iletişim netliği, karar verdikten sonra dönmeme durumu ve ilişkilerdeki şeffaflığın zaman zaman azalması iş ve fakülteyle ilgili süreçlerde direkt etkiye sahip olduğu için ilk etapta törpülenebilecek ve iyileştirilebilir başlıklar arasında yer almaktadır. 3. dekan için ilk öneri sosyal çıkarlarla güdülenme özelliğinden daha çok beslenebilmesidir. Risk alma davranışının daha çok seçilmesi, çalışanlarla birlikte ortaya çıkacak sinerjiyi güçlendirmek adına diğer bir öneri başlığıdır. Hataları kabullenme düzeyi ve düzeltme sürecindeki çabaları daha bütüncül olabilir. Ayrıca 3. dekan, katılımcı olma çabası ile görüş almayı sınılandıran haller arasında sıkışmayı çözerek, insanların yeteneklerini güce dönüştüren bir lider profiline yaklaşabilir. Son olarak otantik liderliğe en yakın profili çizen 4. dekanın, kırmızı çizgi ve kurallarındaki netliği esnetebilme konusunda kendini geliştirmesi, sosyal çıkarlarla güdülenme düzeyini yükseltmesi, kişiliğindeki kapalı ve çekingen yanları aşıp daha rahat bir iletişim tarzı benimsemesi otantik liderlik konusunda gelişimini destekleyebilecek öneriler arasında düşünülmektedir.

\section{Sonuç}

Türkiye ve özellikle dünyada son dönemde çok ilgi gören kavramlardan biri olan otantik liderliği akademisyenler üzerinde inceleyen bu araştırmada; kavram otantik liderliğe ilişkin özellikler, unsurlar ve sinerjiyi etkileyen faktörler üzerinden ele alınmıştır. Araştırma sonucunda, örneklem grubu içinde en çok referans tespit edilen fakülteler 2. ve 4. fakültelerdir. Bu fakültelerde görev alan her iki dekanın da kadın oluşu göz önüne alındığında, kadınların 1. ve 3. fakültelerdeki erkek dekanlara göre otantik liderliğe daha yatkın olduğu söylenebilir. Çalışmada referans sayısı anlamında 2. fakülte, referans içeriği anlamında ise 4. fakülte dekanlarının otantik liderliğe yakın bir profile sahip olduğu dikkati çekmektedir. Örneklem kapsamında sosyal bilimlere oranla, fen ve doğa bilimlerinden gelen dekanlar da otantik liderliğe ilişkin daha çok bulguyla karşılaşılması, araştırmanın bir başka dikkat çeken sonucudur. Araştırmaya konu olan dekanların her biri otantik liderlik ile ilgili örtüşme ve farlılıklara sahipken, 1 . ve 2 . dekanların otantik liderliğin dışında, karizmatik liderlik ve koç tipi liderlik anlayışlardan da etki aldığı görülmüştür. Bunun yanı sıra; risk alma davranışının görülme azlığı, ilişkilerde şeffaflı̆ın tam anlamıyla korunmaması ve kararlar öncesinde tarafsız bilginin sağlanamaması konularında, örneklem grubu içindeki dekanların sıkıntılar yaşadığı görülmektedir. Dekanlarda yaşanan bu sıkıntıların nedenleri arasında kişilik özellikleri ile toplumsal ve kültürel baskıların etkili olduğu düşünülmektedir. Kişilerin iletişime kapalı, çekingen yanları, hataları kabul etmeme konusundaki dirençleri kişiliklerinin törpülenmesi ve geliştirilmesi gereken tarafları arasındadır. Risk alamama, bilgiyi tarafsı değerlendirememe ve sinerjiyi güçlendirememe gibi sorunlarda ise toplumsal ve sosyal etkilerden söz etmek mümkündür. Ata erkil bir ülkede akademik platformda kadınların otantik liderliğe yatkınlığı hali hazırdaki cinsiyet özeliklerinin bu yaklaşımla kolay bütünleşebilecek benzerlikler içerdiği düşüncesini akla getirmektedir. Fen ve doğa bilimlerinin, sosyal disiplinlere ait fakültelere oranla daha çok referans almasının nedenleri literatürde 
yapılacak yeni çalışmalarla sorgulanabilir. Ayrıca araştırmaya lider boyutunun yanı sıra çalışan boyutunu ekleyerek akademik platformda durumu inceleyen yeni çalışmalar da yapılabilir.

\section{Kaynaklar}

Aquino, K. \& Reed, A., II (2002). "The Self-Importance of Moral Identity", Journal of Personality and Social Psychology, 83(6), 1423-1440.

Avolio, B. J. (1999). Full Leadership Development: Building The Vital Forces in Organizations. Thousand Oaks, CA7 Sage.

Avolio, B. J., Gardner, W. L., Walumbwa, F. O., Luthans, F. \& May, D. R. (2004). “Unlocking The Mask: A Look at The Process by Which Authentic Leaders Impact Follower Attitudes and Behaviors", The Leadership Quarterly, 15(6), 801-823.

Avolio, B. J. \& Gardner, W. L. (2005). “Authentic Leadership Development: Getting to The Root of Positive Forms of Leadership", The Leadership Quarterly, 16(3), 315-338.

Avolio, B. J., Walumbwa, F. O. \& Weber, T. J. (2009). "Leadership: Current Theories, Research, and Future Directions", Annual Review of Psychology, 60(1), 421-449.

Boatwright, K. J. \& Forrest, L. K. (2000) "The influence of gender and needs for connection on workers' ideal preferences for leadership behaviors" . Journal of Leadership Studies, 7, 18-34.

Csikszentmihalyi, M. (2003). Good Business. Leadership, flow and the making of meaning. London: Coronet Books, Hodder \& Stoughton eds.

Colby, A. \& Damon, W. (1992). Some Do Care: Contemporary Lives of Moral Commitment. New York, NY: The Free Press.

Dorn, F., Buckley, M. R. \& Brown, J. A. (2005). Barnard on Conflicts of Responsibility Implications for Today's Perspectives on Transformational and Authentic Leadership. Management Decision, 43, ss.1396-1409.

Ersoy, E. (2009). Cinsiyet Kültürü İçerisinde Kadın ve Erkek Kimliği (Malatya Örneği), Fırat Üniversitesi Sosyal Bilimler Dergisi, Cilt:19, Sayı:2, Sayfa: 209-230, Elazı̆̆.

Galperin, B., Bennett, R. \& Aquino, K. (2011). "Status Differentiation and The Protean Self: A Social-Cognitive Model of Unethical Behavior in Organizations." Journal of Business Ethics, 98(3), 407-424.

Gardner, W. L., Avolio, B. J., Luthans, F., May, D. R. \& Walumbwa, F. (2005). “Can You See The Real Me?:" A Self-Based Model of Authentic Leader and Follower Development. The Leadership Quarterly, 16(3), 343-372. 
George, B. (2003). Authentic Leadership: Rediscovering The Secrets to Creating Lasting Value. San Francisco, CA7 Jossey-Bass.

George, W. \& Sims, P. (2007). True North: Discover Your Authentic Leadership. San Francisco, CA: Jossey-Bass.

Goffee, R. \& G. Jones. (2005). "Managing Authenticity: The Paradox of Great Leaders", Harvard Business Review, 83:12, s.86-94.

Harter, S. (2002). Authenticity. C.R. Snyder ve S. Lopez (Der.), Handbook of Positive Psychology:. Oxford University Press, Oxford, UK. 382-394.

Hughes, L. W. (2005). Developing Trasparent Relationships Through Humor in The Authentic Leader-Follower Relationship, Monographs in Leadership and Management, 3, s.83-106.

Ilies, R., Morgeson, F. P. \& Nahrgang, J. D. (2005). "Authentic Leadership and Eudaemonic Wellbeing: Understanding Leader-Follower Outcomes." The Leadership Quarterly, 16(3), 373394.

Kadının Statüsü Genel Müdürlüğü, (2012). Türkiye'de Kadının Durumu Raporu, T.C. Aile ve Sosyal Politikalar Bakanlığı, Ankara.

Kernis, M. H. (2003). "Toward a Conceptualization of Optimal Self-Esteem." Psychological Inquiry, $14(1), 1-26$.

Kesken J. \& Ayyıldız N. A. (2008). "Liderlik Yaklaşımlarında Yeni Perspektifler: Pozitif ve Otantik Liderlik," Ege Akademik Bakış, 8 (2), 729-754.

Luthans, F. \& Avolio, B. (2003). Authentic Leadership: A Positive Development Approach. In K. S. Cameron, J. E. Dutton, \& R.E. Quinn (Eds.), Positive Organizational Scholarship (pp. 241-258). San Francisco, CA7 Berrett-Koehler.

Luthans, F., Norman, S. \& Hughes, L. (2006). Authentic Leadership: A New Approach for a New Time. In R. J. Burke \& C.L. Coopers (Eds.), Inspiring Leaders (pp. 84-104). London, UK: Routledge.

Luthans, F., \& Youssef, C. M. (2004). Human, social, and now positive psychological capital management: Investing in people for competitive advantage. Organizational Dynamics,33: 143160.

May, D. R., Chan, A. Y. L., Hodges, T. D. \& Avolio, B. J. (2003). “Developing the Moral Component of Authentic Leadership." Organizational Dynamics, 32(3), 247-260.

Mazutis, D., \& Slawinski, N. (2008). Leading organizational learning through authentic dialogue. Management Learning, 39(4), 437-456.

Moir, A. \& Jessel, D. (2002). Beyin ve Cinsiyet, (Çev.Tarık Demirkan), Pencere Yayınları, İstanbul. 


\section{Güzin KIYIK KICIR | Didem PAŞAOĞLU}

Özdemir M. (2011). Nitel Veri Analizi: Sosyal Bilimlerde Yöntembilim Sorunsalı Üzerine Bir Çalışma, Eskişehir Osmangazi Üniversitesi Sosyal Bilimler Dergisi, 11(1).

Özdil, Aydın, E. (2009). Dönüşümcü Liderlik ve Toplumsal Cinsiyet Rolleri Arasındaki Ilişkinin İncelenmesi, Ankara Üniversitesi, Sosyal Bilimelr Enstitüsü, Psikoloji Anabilim Dalı, (Yüksek Lisans Tezi).

Shamir, B. \& Eilam, G. (2005). "What's Your Story? A Life-Stories Approach to Authentic Leadership Development." The Leadership Quarterly, 16(3), 395-417.

Shao, R., Aquino, K. \& Freeman, D. (2008). "Beyond Moral Reasoning: A Review of Moral Identity Research and Its Implications for Business Ethics." Business Ethics Quarterly, 18(4), 513-540.

Stelter, N.Z. (2002). "Gender differences in leadership: current social issues and future organizational implications". The Journal of Leadership Studies, 8(4).

Treviño, L., Weaver, G. \& Reynolds, S. J. (2006). "Behavioral Ethics in Organizations: A Review." Journal of Management, 32(6), 951-990.

Walumbwa, F. O., B. J. Avolio, W. L. Gardner, T. S. Wernsing \& S. J. Peterson. (2008). “Authentic Leadership: Development and Validation of a Theory-Based Measure", Journal of Management, XXXIV: 1, s.89-126.

Walumbwa, F. O., Wang, P., Wang, H., Schaubroeck, J. \& Avolio, B. J. (2010). "Psychological Processes Linking Authentic Leadership to Follower Behaviors." The Leadership Quarterly, 21(5), 901-914.

Walumbwa, F., Luthans, F. , Avey, J. \& Oke, A. (2011). “Authentically Leading Groups: The Mediating Role of Collective Psychological Capital and Trust", Journal of Organizational Behavior, 32,4-24.

Ward, B. (2006). The Authentic Leader: Losing the Mask, http://www.affinitymc.com/the_authentic_leader.htm.

Wood, M. A., P. A. Linely,, J. Maltby,, M. Baliousis \& S. Joseph. (2008). “The Authentic Personality: a Theoretical and Empirical Conceptualization and The Development of The Authenticity Scale". Journal of Counseling Psychology. 55(3), 385-399.

Yıldırım, A. \& Şimşek, H. (2006). Sosyal Bilimlerde Nitel Araştırma Yöntemler. Ankara: Seçkin Yayınları, 224. 